\title{
PRELIMINARY STUDIES OF ANALYZING MISCONCEPTION AND SCIENTIFIC ARGUMENTATION USING DIAGNOSTIC QUESTION CLUSTERS (DQCS) OF MOLECULAR GENETICS CONCEPT
}

\author{
Lela Nurlaila*1, Siti Sriyati ${ }^{2}$, Riandi $^{3}$ \\ ${ }^{1,2,3}$ Departemen of Biology Education, Indonesia University of Education, \\ Jl. Dr. Setiabudi no 229, Bandung 40154, Indonesia \\ nurlailalela29@gmail.com
}

\begin{abstract}
:
This study aimed to analyze the misconceptions and argumentation ability Biology education students using diagnostic question clusters on the concept of molecular genetics. In addition, this study aims to look at the pattern of misconceptions tendencies and scientific argumentation ability of students accompanied by the factors supporting the occurrence of misconceptions and arguments student achievement levels. As this study focused on the concept of molecular genetics which includes the concept of genes, chromosomes, DNA, and protein synthesis. This research was conducted with the descriptive research method and the sample using purposive sampling techniques. The subjects were biology education students of Islamic University of Sunan Gunung Djati Bandung who attended the lectures of genetics in the academic year 2014/2015. The instrument used is a matter of diagnostic question clusters (DQCs) which covers a combined essay and multiple choice questions, learning observation sheet, and interview guidelines used to determine the factors that cause the occurrence of misconceptions and what degree of scientific argumentation ability students. The ability of the scientific arguments that will be analyzed is the ability to claim, warrant, backing, and rebutal (Toulmin, 1984).
\end{abstract}

Key Concept : Misconception, Scientific Argumentation Skill, Diagnostic Question Clusters (DQCs), molecular genetic.

\section{INTRODUCTION}

Biology is one of science subject matter that includes concepts that are concrete and abstract concepts. Biological materials abstract be one of the sources of difficulty in understanding the concepts students are causing misconceptions. One of biological materials that are difficult to understand by most students is the genetic material concept (Meilinda, 2009). The misconception is not just happening in the students of primary and secondary school level, but the level of high school students until the students were told there students who experienced misconception especially for concepts that require deep understanding. Just as in biological materials, which have the abstract concepts that can not be explained in real terms. Based on the results of an initial interview with a lecturer of the course Genetics (2015) note that the genetic material that is highly vulnerable to any misconceptions or fail to understand the concept is in 
subconcepts cell reproduction, genetic control (protein synthesis and gene expression), as well as the basic concepts of relationship genes, DNA and chromosomes. In addition, according Venville (2002) adds that the genetic material included in the material a tedious and tiring. It can happen one of them is that students tend to memorize concepts compared to apply concepts, besides genetics are biological materials that constitute the conceptual knowledge that contains some complex concepts (Urey and Calik, 2008). The results of the research to the understanding of genetics concepts made by Infante-Malachias, et al (2010) suggests that approximately $15 \%$ of the students are unable to provide an explanation of the chromosomes, and $70 \%$ of students give incorrect explanation of the process of mitosis and meiosis. In addition, based on research results Wangintowe (2008) at the upper secondary level school students in the city of Palu in mind that students have misconceptions on the concept of chromosomes (76.1\%), genes $(75.0 \%)$ and DNA $(76.5 \%)$ and protein synthesis $(63.1 \%)$. Understanding the concept of the genetic material is essential as a basis for understanding other concepts in other biological concepts. It can be said that understanding the concept of genetics is a prerequisite for understanding other concepts such as biotechnology (Tekkaya, 2006). National Research Council (1996) suggest that the science learning should promote the teaching for understading, but in reality their science lessons in college now synonymous with the provision of comprehensive science course content. Basically, the provision of comprehensive content in college is important to convey to the students, but to ensure that students understand the whole content should also be analyzed using the capabilities of higher order learning schemes include the ability of reasoning or in other words is the ability of the scientific argument. Over the last two decades the ability of argumentation becomes very interesting in science education in university education (Kuhn, D. 2010). Based on the research results Kurniadi, et al (2015) argued that the ability of high school students in Bandung on learning biology is still not well developed. It can be seen from the percentage of the level of ability that decreases from the lowest to highest. Decrease in the ability of these arguments are influenced by the methods and strategies of teaching teachers. Through these studies it is known that high school students in the city of Bandung is still not able to develop the ability of the argument. So it is very interesting, especially what arguments the ability of students in college, whether the result will be the same as the argument ability of high school students or it will be better. Based on the interview with one of the lecturer of the course genetics (2015) note that the lecturer has struggled to develop questions or questions that can stimulate students to think of using the theory / concept of relevant science that can explain the data obtained as the basis for a claim scientific argument, so if the ability of this argument is not developed, the students' answers to the question is feared will have misconceptions. So that measure students' conceptual understanding has become increasingly important to the biology faculty members were involved in evaluating and improving departmental programs (Couch et al, 2015). It needed the assessment tool to identify and detect the extent of scientific argumentation ability of students to questions about the concept of genetically so that it can detect the tendency of their misconceptions. Assessment tools that can be used as an alternative in identifying the ability of scientific arguments (scientific reasoning) and the tendency of their misconceptions include Question Diagnostic Clusters (DQCs). Question Diagnostic Cluster is one concept conceptual inventory or assessment in biology (Fisher, 2010). According Suwirto (2013) that the 
diagnostic test is useful to know the learning difficulties faced by the students, including the misunderstanding of the concept. The results of the diagnostic tests provide information about the concepts that have not been understood and that was understood. Through the use of group diagnosis in a test question can provide the opportunity for students to be able to think like a scientist biology "thinking like a biologists'. The important aspect to think like scientists in biology is always apply the basic principles of scientific argument (reasoning). Besides this, there are several studies also use diagnostic tests to determine students' understanding of the molecular and cell biology (Shi et al, 2010). Some diagnostic tests may be used to determine the understanding of concepts and misconceptions which are diagnostic question clusters (DQCs) and interviews. According Treagust (2007) that this type of test is used to reduce the student can guess the answer, because they are required to give arguments (reasoning) so it can know the extent of their understanding of a concept. In addition, based on research results Hartley et al (2011) also explained that the function of the Diagnostic Question Clusters (DQCs) is to measure comprehension through the ability of argumentation based on scientific principles, as an assessment tool that can inform learning difficulties students and their misconceptions learners to a concept. Based on the background of the above problems, the authors are interested to do research with the title Analysis of misconception and Capabilities argument Student Science Biology Education by Using Diagnostic Question Clusters (DQCs) on the concept of Molecular Genetics with a problem of this research is "What is the profile of misconceptions and the ability of scientific argumentation biology education students using Diagnostic instrument Cluster Question (DQCs) on the concept of molecular genetics? ". The research objective to be achieved in general is to analyze misconceptions and scientific argumentation ability of biology education students using the instrument cluster diagnostic question (DQCs) on the concept of genetics. In particular the research objectives to be achieved are as follows: 1 . Analyze misconceptions biology education students on the concept of genetics 2 . Analyzing the ability of scientific arguments biology education students on the concept of genetics 3. Uncover the tendency pattern of misconceptions and scientific argumentation ability of biology education students on the concept of genetics The results of this study are expected to provide benefits as preliminary information for the lecturers of the misconceptions and the ability of scientific argumentation experienced by students of biology education who take courses in genetics, and as study materials to anticipate the possibility of misconceptions in students when the learning process and informing them of alternative instruments upon ability in analyzing the scientific arguments and misconceptions. Results are expected to be the basis for further research, especially in developing diagnostic question cluster (DQC) as an instrument in analyzing misconceptions and scientific argumentation ability of biology education students, as well as preliminary information on further action to anticipate any misconceptions in students.

\section{METHOD}

The method used is descriptive method. Research by this method is used to analyze the data in ways that describe or depict the data that has been collected by the instrument DQCs as it is. The population of this study were all students of biology education UIN Sunan Gunung Jati Bandung who take the classes genetics academic year 2014/2015. The sampling technique used in this research is purposive sampling. This technique is a technique of sampling data source with a certain considerations. The sample of this research 
is a biology education students who follow courses of Genetics in the academic year $2014 / 2015$ of 20 people. The independent variables in this study were analyzed misconceptions aspect of the students' answers on DQCs given the lead to the genetic material and the use of assessment rubrics Morgil and Yoruk (2002). The ability of a scientific argument as independent variables in this study were analyzed based on the quality of student writing arguments. The dependent variable in this study is the Problem Question Diagnostic Clusters (DQCs). Argument writing in this study is a written response (claim, warrant, backing, and rebutal) against the stand point that is given by using questions DQCs developed into a two-tier DQCs type of test or multiple choice questions about the type of reasoned and essays. Observation sheet used as an instrument to measure the adherence to the learning process in the classroom during the study. This observation sheet aims to identify the learning process that occurs in the classroom so that it can support data capabilities misconceptions and scientific arguments that have been obtained. Notes field is used as a supporting instrument in this study in order to get the field data during the study process. Notes field will be obtained through field data collection tool such as stationery, recorders, cameras, and others.

\section{RESULT AND DISCUSSION}

This paper is a publication of the results of preliminary research on misconceptions and argumentation ability students who attend lectures in public universities sunan genetics mountain djati Bandung. The results of this study are the basic for further research to students who take the classes genetics academic year $2015 / 2016$. Their misconceptions or will not be captured by using the diagnostic question clusters (DQCs), as well as the ability of the argument. Both use a different rubric. Identifying misconceptions can be known through the rubric of understanding of concepts in the adaptation of Morgul and Yoruk (2006):

Table 1. Rubric assessment misconceptions

\begin{tabular}{|l|l|}
\hline \multicolumn{1}{|c|}{$\begin{array}{c}\text { Conceptual } \\
\text { understanding }\end{array}$} & \multicolumn{1}{c|}{ criteria } \\
\hline Understood & $\begin{array}{l}\text { The answer to each concept statement shows } \\
\text { mastery of concepts }\end{array}$ \\
\hline understood partially & $\begin{array}{l}\text { Answer demonstrate mastery of concepts that } \\
\text { marked their partial (at least one) feature or } \\
\text { element answers represent mastery of } \\
\text { concepts }\end{array}$ \\
\hline $\begin{array}{l}\text { Understood partially } \\
\text { accompanied } \\
\text { misconceptions }\end{array}$ & $\begin{array}{l}\text { Answers indicate that understood the concept } \\
\text { but contains statements that misconception }\end{array}$ \\
\hline $\begin{array}{l}\text { Misconception } \\
\text { Do not understand }\end{array}$ & $\begin{array}{l}\text { Answer that contains information that is not } \\
\text { logical or appropriate }\end{array}$ \\
$\begin{array}{l}\text { Answer indicate: (1) Repetition question / } \\
\text { statement (2) The answer is of no relevance } \\
\text { to the statement (3) The answer "I do not } \\
\text { know / understand"; (4) No answer or not } \\
\text { filled }\end{array}$ \\
\hline
\end{tabular}

From: Morgil dan Yörük (2006) 
Based on the results of the deployment of about Question Diagnostic Clusters (DAS) with the concept of genes, chromosomes, DNA and Protein Synthesis obtained the following results:
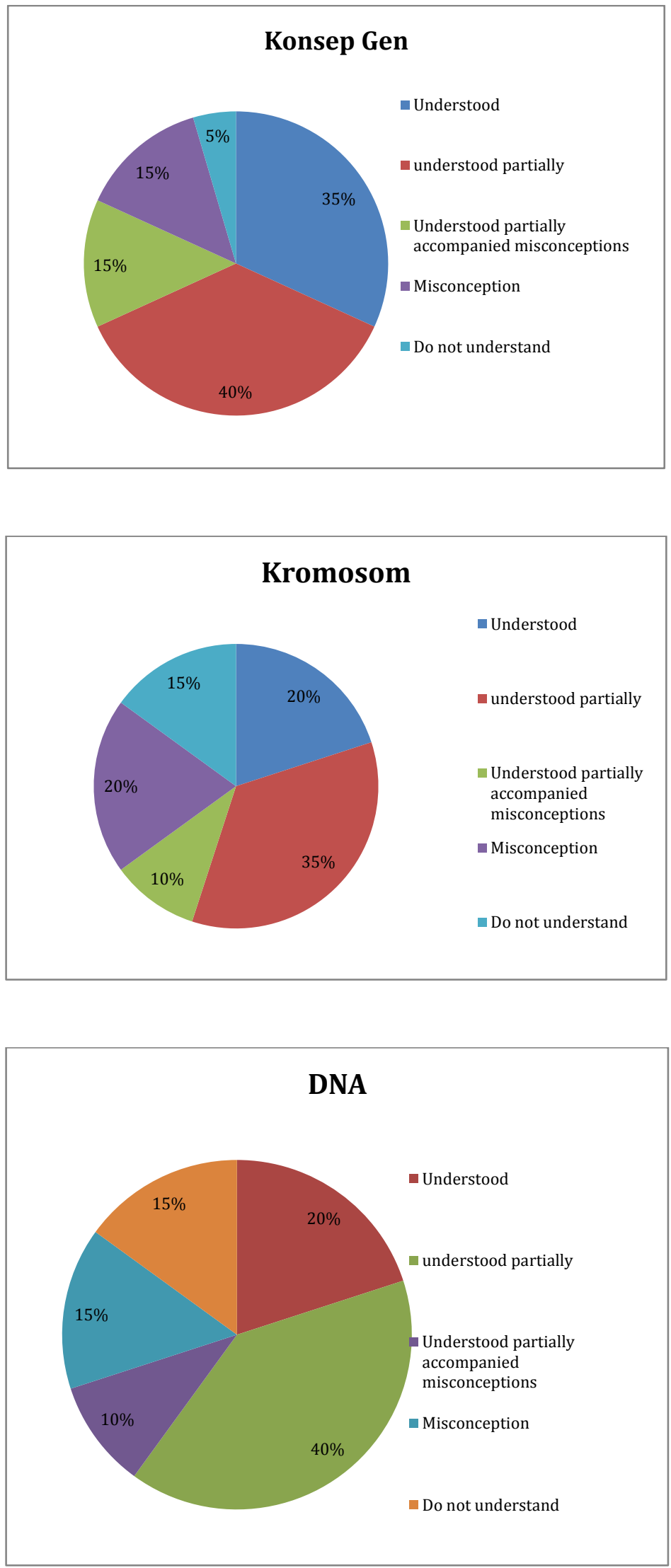


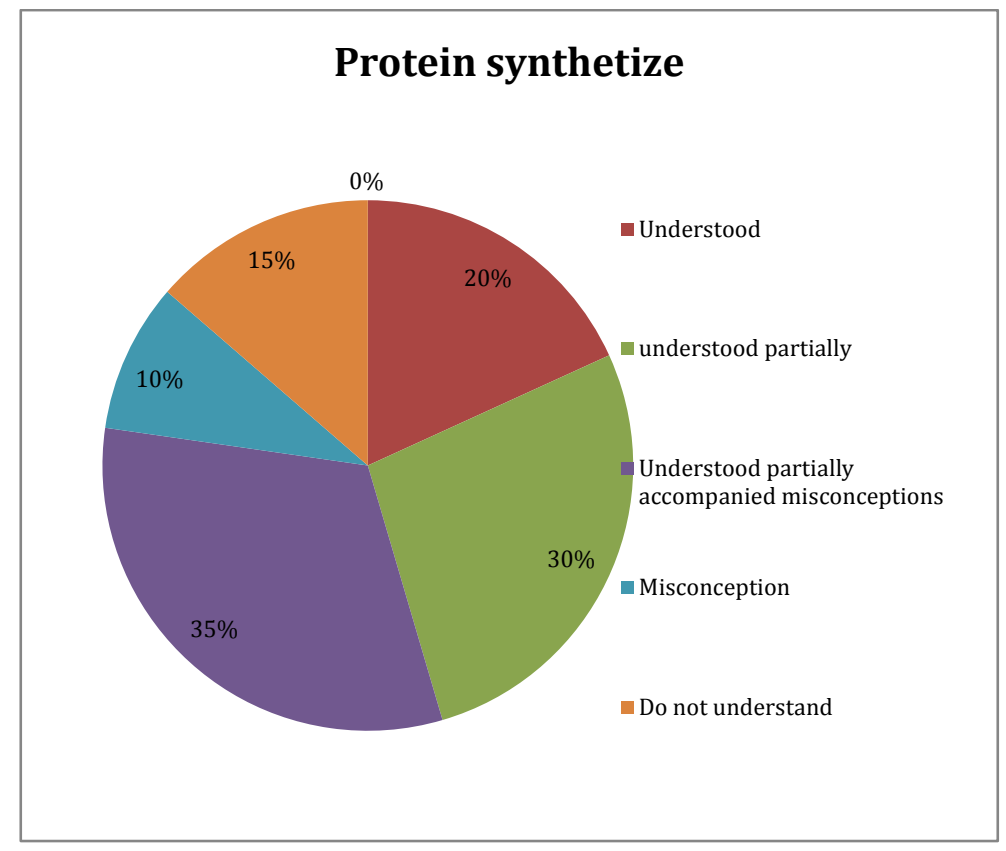

Based on the description above, it can be described as to how many misconceptions that occur on the concepts above:

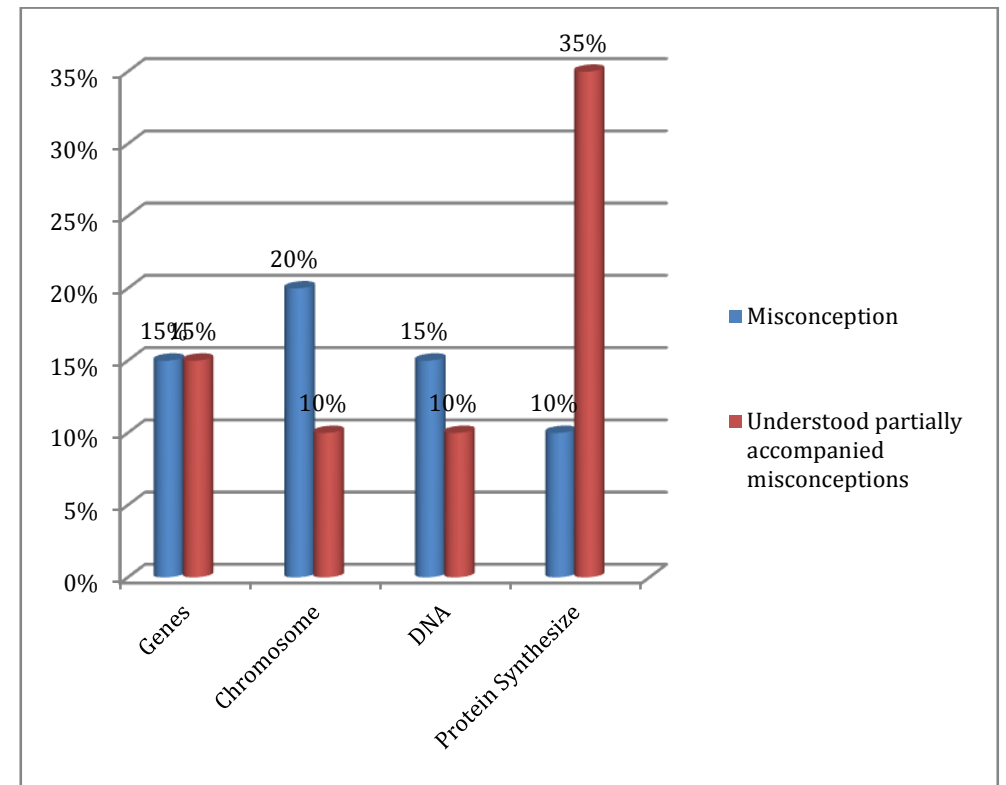

From the students' answers were analyzed and depicted in the graph above it is known that the highest misconceptions of students occurs most commonly in the concept of chromosomes (20\%), genes $(15 \%)$, DNA $(15 \%)$, and protein synthesis $(10 \%)$. 


\begin{tabular}{|c|c|c|}
\hline \multicolumn{1}{|c|}{ Concept } & $\begin{array}{c}\text { Total } \\
\text { percentage } \\
\text { Misconceptions }\end{array}$ & \multicolumn{1}{|c|}{ misconceptuon's statement } \\
\hline \multirow{2}{*}{ Genes } & $15 \%$ & $\begin{array}{l}8 \% \text { student replied "Genes and DNA } \\
\text { are the same" } \\
\text { student replied "Genes determine } \\
\text { the types of properties, and DNA } \\
\text { determines many types of } \\
\text { properties" }\end{array}$ \\
\hline Chromosome & $20 \%$ & $\begin{array}{l}\text { student answered "chromosomes in } \\
\text { each cell nucleus of living beings" }\end{array}$ \\
\hline DNA & $15 \%$ & $\begin{array}{l}\text { student answered "DNA is a sequence } \\
\text { that can be transcribed and translated }\end{array}$ \\
\hline Protein & $10 \%$ & $\begin{array}{l}\text { student replied "protein produced from } \\
\text { the process of transcription and } \\
\text { translation" }\end{array}$ \\
\hline
\end{tabular}

The analysis of the ability of argumentation of 20 students biology education is captured by using the same instrument clusters namely diagnostic question (DQCs) type multiple choice questions and essays reasoned. Here are the results of preliminary research on the analysis of the ability of student scientific arguments that are based on rubric structure of argumentation Toulmin (1984), using 15 questions DQCs with 10 PG groundless and 5 essay:

\begin{tabular}{|l|l|l|l|}
\hline Code & Mean & \multicolumn{1}{|c|}{ Description } & \multicolumn{1}{c|}{ Linguistics features } \\
\hline CCC & Claim & $\begin{array}{l}\text { Claim based } \\
\text { ofstandpoint }\end{array}$ & $\begin{array}{l}\text { I agree with... } \\
\text { I support.... } \\
\text { In my opinion ... is right .. } \\
\text { I do not agree.. } \\
\text { I disagree .. } \\
\text { In my opinion ... not appropriate .. }\end{array}$ \\
\hline W & Warrant & $\begin{array}{l}\text { There is a } \\
\text { guarantee of the } \\
\text { justification of the } \\
\text { claim }\end{array}$ & $\begin{array}{l}\text { I agree with ... because ... } \\
\text { Why I support .. because ... } \\
\text { Things that make me disagree is ... }\end{array}$ \\
\hline
\end{tabular}




\begin{tabular}{|c|c|l|l|}
\hline Code & Mean & \multicolumn{1}{|c|}{ Description } & \multicolumn{1}{c|}{ Linguistics features } \\
\hline B & Backing & $\begin{array}{l}\text { There is data or } \\
\text { facts that support } \\
\text { warrant }\end{array}$ & $\begin{array}{l}\text { Based on my experience ... } \\
\text { According to what is contained in the } \\
\text { book ... } \\
\text { Like the fact that we all know ... } \\
\text { Data / facts / phenomena ... prove }\end{array}$ \\
\hline R & Rebutal & Argument & $\begin{array}{l}\text { I do not agree with you ... I think ... does } \\
\text { not fit ... The statement seems less } \\
\text { appropriate .... I do not agree with the } \\
\text { reasons ... }\end{array}$ \\
\hline RB & $\begin{array}{c}\text { Rebutal } \\
\text { of } \\
\text { warrant }\end{array}$ & $\begin{array}{c}\text { Argument of } \\
\text { warrant } \\
\text { of } \\
\text { backing }\end{array}$ & $\begin{array}{l}\text { I do not agree with you .... } \\
\text { I think ... does not fit ... } \\
\text { The statement seems less appropriate .... } \\
\text { I do not agree with the reasons ... }\end{array}$ \\
\hline backing & $\begin{array}{l}\text { I do not agree with .... but the data is not } \\
\text { quite right ... }\end{array}$ \\
\hline
\end{tabular}

From the student answers the question docs later identified as follows:

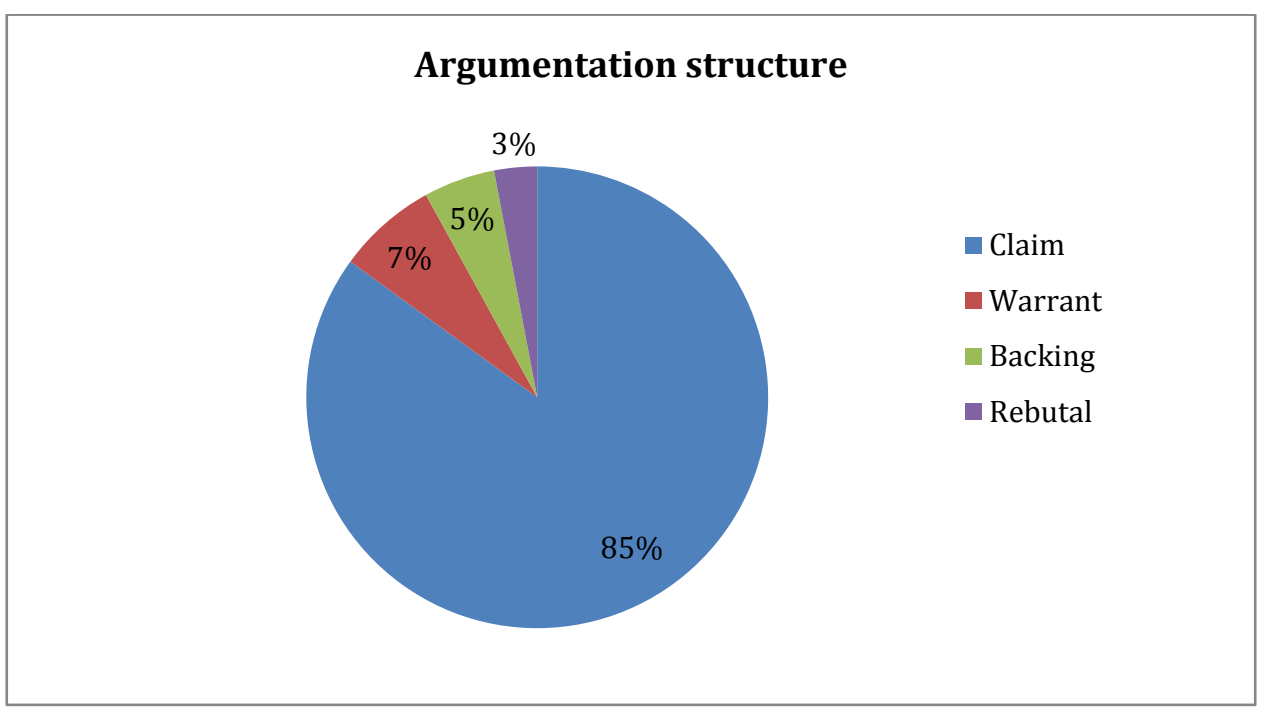

From the graph above it is known that most arguments capabilities possessed by the students is the ability of the warrant $(85 \%)$.

\section{CONCLUSION}

This study is a preliminary study aims to determine and identify misconceptions and argumentation abilities biology education students on the concept of molecular genetics (genes, chromosomes, DNA, and protein synthesis). Based on these results it is known that there are many misconceptions occur on the concept of chromosomes (20\%), genes (15\%), DNA (15\%) and protein synthesis (10\%). Through the use of Question Diagnostic Clusters (DQCs) is also known that the ability of the student's argument still has the ability Warrant (the ability to give a reason / grounding of choosing an answer). 


\section{REFERENCES}

Albert, B., Johnson A., Lewis J.,2007, Molecular Biology of the Cell 5 ed.London:Garland Science

Aunurrahman.(2008). Belajar dan Pembelajaran cetakan ke-4. Bandung: Alfabeta

Barry, Vincent (1980). Good reason for writing (Contents argument and the argumentative essay). Belmont: Wadsworth Publishing Co

Bell, P \& Linn, M.C (2007). Scientific argument as learning artifact, designing for learning from the web with KIF. International journal of science education, 22 (8), 797-817

Brueckener \& Melby.(1981).Diagnostic and Remedial Teaching. Boston: Hpughton Mifflin Company

Campbell N.A. Mitchell LG, Reece JB, Taylor MR, Simon EJ. 2009.

Biology, 5th ed. Benjamin Cummings Publishing Company, Inc., Redword City, England.

Clark, P, David. 2010. Molecular Biology. Ukraina: APCell Press

Couch et al., (2015). The molecular biology Capstone Assessment : A concept -Assessment for upperDivision Molecular Biology Students. CBE- life science education Vol 14 1-11

Crowder.(2006). Genetika Tumbuhan. Yogyakarta: UGM press

D’Avanzo,C., Anderson, W.C.,. Hartley, M.L, and Pelaez, N. (2012). Faculty-Development Model For Transforming Introductory Biology and Ecology Courses. Bio Science. Vol. 62 No. 4. 416-427

Dahar, R.W. (1989). Dasar-Dasar Teori Belajar. Jakarta: Erlangga

Dauer et al., (2014). Connection between student explanations and arguments from evidence about Plant Growth. CBE-Life science education 397409

Eemeren, V., Grootendorst, R., Henkemans, A, (1996) Argumentation Analysis,
Evaluation, Presentations. London:

Lawrence Erlbaum Associates

Publisher.

Erduran, S \& Maria, PJ. (2004) Argumentation in science education. London: Springer

Erduran, S., Simon., \& Osborne, J. (2004), TAPing into argumentation: Developments in the application of Toulmin's argument pattern for studying science discourse, Science Education, 88, 915-933

Fachtiyah, et al (2011). Biologi Molekuler. Jakarta: Erlangga

Fisher, K.M, Williams, K.S, and Lineback, J.E. (2011) Osmosis and Diffusion Conceptual Assessment. CBE-Life science education Vol. 10, 418-429

Gronlund, N.E (1985). Measurement and evaluation in teaching. New York : Mcmillan Publishing co.Inc

Hartley L, Wilke B, Schramm J, D’Avanzo C, Anderson A (2011). College students' understanding of the carbon cycle: contrasting principlebased and informal reasoning. Bioscience 61, 65- 75.

Haslam, F \& Treagust, D.F (1987). Diagnosing secondary students misconceptions of photosynthesis and respiration in plants using two tier multiple choice instrument. Journal of biological education, 21 (3), 203-211

Herlanti. (2007). Tanya Jawab Seputar Penelitian Pendidikan Sains. Jakarta :Jurusan Pendidikan IPA Fakultas Tarbiyah dan Ilmu Keguruan Universitas Islam Negeri Syarif Hidayatullah Jakarta.

Infante-Malachias, M. E. et. al. (2010). Comprehension of basic genetic concepts by brazilian undergraduate students. Electronic Journal of Science Education Vol. 9 No. 3, 657-668

Karp, G.2013. Cell and Molecular Biology : concept and experiments. United 
States Of America. John-Willey and Sons Inc.

Keraf, Gorys (2004). Argumentasi dan Narasi. Jakarta:Gramedia Pustaka Utama

Khrisnan, S.R \& Howe, A.C. (1994). The mole concept: Developing an instrumen to assess conceptual understanding. Journal of chemical education, 71 (8), 653-655

Krajcik J, McNeill KL (2009). Designing Instructional Materials to Support Students inWriting Scientific Explanations. Paper presented at the National Association for Research in Science Teaching conference, April 17-21, 2009, Garden Grove, $C A$

Kuhn, D. (2010). Teaching and learning science as argument. Science Education 94, 810-824.

Lacum, et al. (2013). A teaching strategy with a Focus on Argumentation to Improve Undergraduate students ability to read research articles. CBE-life science education Vol 13 253-264

Lewis, J. \& Kattmann, U. (2004). Traits, genes, particles and information: re-visiting students' understanding of genetics. International Journal of Science Education, 26, 195-206.

Manurung, S.R \& Rustman, N.Y. (2012). Identifikasi Keterampilan Argumentasi Melalui Analisis "Toulmin Argumenation Pattern(TAP)" Pada Topik Kinematika Bagi Mahasiswa Calon Guru.

Mardapi, D. (2004). Penyusunan Tes Hasil Belajar. Yogyakarta:Program Pascasarjana UNY

Mbajiorgu, N., Ezechi, N., \& Idoko, C. (2006). Addressing nonscientific presuppositions in genetics using a conceptual change strategy. Science Education, 419-438.

Meilinda. (2009). E-modul Interaktif berbasis Kontruktivisme pada Materi Genetika untuk meningkatkan Kompetensi Guru Biologi SLTP. Tesis Jurusan Pendidikan IPA. Sekolah Pascasarjana Universitas Pendidikan Indonesia: Tidak diterbitkan

Morgil, İnci dan Yörük, Nuray. (2006). Cross-Age Study of The Understanding Of Some Concepts In Chemistry Subjects In Science Curriculum. Journal of Turkish Science Education 3[1].

Muslim, I.2003. Assasmen Berkelanjutan; Konsep Dasar Tahap Pengembangan dan Contoh. Surabaya: UNESA University Press Mustika et al.(2014).Identifikasi Miskonsepsi Mahasiswa Biologi Universitas Negeri Makassar pada Konsep Genetika dengan Metode CRI. Jurnal Sainsmat, September 2014, Halaman 122-129 Vol. III, No. 2 ISSN 2086-6755

Newman et al., (2012). Student fail to transfer knowledge of Chromosome Structure to topics Pertaining to Cell Division. CBE-Life science education, 425-436

Ngili, Yohanis (2009). Biokimia. Yogyakarta: Graha Ilmu

Nusantari, E. (2010). Analisis dan Penyebab Miskonsepsi pada Materi Genetika Buku SMA Kelas XII. Bioedukasi Vol. 4 No. 2 Hal 72-85

Osborne JF, Patterson A (2011). Scientific argument and explanation: a necessary distinction? Sci Educ 95, 627-638.

Osborne, J., Erduran, S. \& Simon, S. (2004). Enhancing the quality of argument in school science.Journal of Research in Science Teaching, 41(10), 994-1020

Parker,J.M*† Anderson, C.W., Heidemann, M., Merrill, J,. Merritt, B., Richmond, G $\ddagger$ dan -Lurain, M.U. (2012) Exploring Undergraduates' Understanding of Photosynthesis Using Diagnostic Question Clusters. CBE-Life 
Sciences Education. Vol. 11, 4757 ,

Pollard, D, Thomas \& Earnshaw, C, William (2008). Cell Biology Second edition. Philladelphia: Saunders Elsevier.

Richmond,G., Merritt, B,. Lurain, M.U dan Parker, J (2010) The Development of a Conceptual Framework and Tools to Assess Undergraduates' Principled Use of Models in Cellular Biology. CBE-Life Sciences Education. Vol. 9, 441452

Rigotii, E.,\& Moraso,G.S. (2009). Argumentation as an object of interest and as social and cultural resources. Argumentation and Education. Dalam N muller Misrza \& A,-N Perret-Clermont (Eds), New York: Springer US.

Roshayanti, F \& Rustaman, N.(2013).Pengembangan Asesmen Argumentatif Untuk Meningkatkan Pola Wacana Argumentasi Mahasiswa Pada Konsep Fisiologi Manusia. Bioma, Vol. 2, No. 1,

Seyler, U, Dorothy. (2010). Read, reason, Write (An argument text and reader) Ninth Edition. New York: Mc Graw Hill Higher Education

Shi, J., Wood, B, Martin, J, Guild, N. Vicens, Q_ and Knight, J. (2010). A Diagnostic Assessment for Introductory Molecular and Cell Biology. CBE-Life Sciences Education. Vol. 9, 453-461,

Smith MK, Knight JK (2012). Using the Genetics Concept Assessment to document persistent conceptual difficulties in undergraduate genetics courses. Genetics 191, 2132.

Stevens, Danelle, D \& Levi, Antonia. 2005. Introduction to rubrics (An assessment tool to save grading time, convey effective feedback, and promote student learning). Virginia: Stylus Publishing, Llc
Suparno. (2005). Filsafat Konstruktivisme dalam Pendidikan. Yogyakarta: Kanisius

Suparno, P. (2005). Miskonsepsi dan Perubahan Konsep Pendidikan Fisika. Jakarta: Agrasindo.

Suprayana, Defi F. (2014). Analisis Penguasaan Konsep dan Miskonsepsi siswa SMA Pada Konsep Genetika. Bandung. Tesis. Tidak diterbitkan

Suwirto. (2013). Pengembangan Tes Diagnostik dalam Pembelajaran. Yogyakarta:Pustaka Pelajar

Tekkaya. (2006). Misconception as a barier to understand biology. Journal of Hacettepe University Education Faculty ,23 259-266

Toulmin, et al (1984). An Introduction to Reasoning. New York: Mc Milan Publishing Co.Inc

Toulmin, Stephen E. (2003). The Uses of Argument. New York: Cambridg

Urey dan Calik. (2008). Combining different conceptual change method within 5E model : A sample teaching design of cell concept and its organelles. Asia pasific forum on science learning and teaching. Volume 9 Issue 2article 12:1-15

Venville, G., Gribble, S., \& Donovan, J. (2004). An exploration of young children's understandings of genetics concepts from ontological andepistemological perspectives. Wiley InterSci, 614-633.

Wangintowe, T. (2008). Miskonsepsi Siswa SMA pada Mata Pelajaran Biologi dan Faktor-faktor Penyebabnya. Disertasi Program Studi Psikologi Pendidikan, program Pascasarjana, Universitas Negeri Malang

www.geneticengineering.com diakses pada 10 april 2016

Yuwono, Triwibowo .(2005). Biologi Molekuler. Yogyakarta:Erlangga 